\title{
Swedish Vocational Adult Education in the Wake of Marketisation
}

\author{
Per Andersson*, Karolina Muhrman \\ Linköping University, Department of Behavioural Sciences and Learning, \\ 58183 Linköping, Sweden
}

Received: 13 July 2021, Accepted: 02 December 2021

\begin{abstract}
Context: This study is about vocational education and training for adults within municipal adult education (MAE). Sweden has a long tradition of adult education, and has one of the world's highest proportions of participants in adult education. The Swedish education system is characterised by extensive marketisation with many private actors, particularly in adult education. The focus of this article is on the enactment of the market orientation in vocational adult education, with the purpose of showing how vocational adult education is organised in different ways in Swedish municipalities and how national adult education policy is enacted in local VET practices.
\end{abstract}

Methods: The data consist of documents presenting relevant national policies for adult education, in particular on vocational education, and semi-structured interviews with adult education leaders in 20 municipalities.

Findings: The findings show that MAE in Sweden has a clear labour market focus on offering education that corresponds to working life's labour requirements. Most municipalities have a shortage of staff in elderly care and childcare, which is why they offer a large number of training places in these professions. Many immigrants choose these training programmes to get a job. It is also common for municipalities to offer these training programmes in combination with SFI (Swedish for immigrants). This means that MAE fulfils an important function for integration. VET in MAE is offered as school-based training, apprenticeships

*Corresponding author: per.andersson@liu.se 
or distance education. Offering VET at a distance makes it possible to provide a wider range of training programmes, and enables people who have difficulties participating in on-site training (due to commitments such as work or young children) to take part. Apprenticeship training provides work experience and often leads to employment. However, a weak interest in apprenticeship training among students and difficulties finding apprenticeship placements are examples of reasons why the number of apprenticeships is often very limited.

Conclusion: Swedish MAE is characterised by flexibility and a broad supply of courses. However, there is a clear focus on certain vocational areas - mainly within the municipal organisation. This gives reason to question whether publicly funded VET for adults should mainly prepare participants for publicly funded labour-market sectors, or whether other sectors could also benefit from newly trained adults. Since vocational training within MAE is of great importance for immigrants' establishment in the labour market, there is a risk that unilateral investments in certain vocations will limit immigrants' career opportunities.

Keywords: Adult Education, Employability, Immigrants, Educational Policy, Vocational Education and Training, VET

\section{Introduction}

Sweden has a long tradition of education that is free and accessible to all residents, from preschool to adult education and higher education. The OECD (2020) specifically describes adult education as a key factor in the education system in terms of inclusion and the possibility of lifelong learning, and Sweden has one of the world's highest proportions of participants in adult education. In 2020, 7 percent of the adult population aged 20-64 - or 400,000 students - took part in municipal adult education, which is more than the number of upper secondary school students in Sweden (Swedish National Agency for Education [SNAE], 2021a, 2021b). According to the Swedish Education Act, municipal adult education (MAE) has a three-part assignment to support adults in their learning: For personal development and a strengthened position in society, for the purpose of enabling further studies, and for a strengthened position in working life (Education Act, 2010). The Education Act stipulates that municipal adult education must form a basis for national and regional skills supply for working life. During the last decade, the labour market focus has become more visible in Swedish MAE through the introduction of various government grants that have greatly increased the number of vocational education places. One reason why the number of places has increased is the large number of immigrants who came to Sweden in the 2010s. To establish themselves in the labour market, many immigrants are offered the opportunity (or are encouraged) to study vocational training programmes at MAE (Andersson \& Muhrman, 2021b). 
In addition to being free and accessible to all residents, the Swedish education system is characterised by extensive marketisation. A large number of external, private actors have established themselves in the education market since the mid-1990s, and besides this external marketisation there is also an internal marketisation with more business-like management of public institutions (Dahlstedt \& Fejes, 2019b; Lundahl et al., 2013). There has been a particularly strong trend of marketisation in adult education. A quasi-market has developed where many municipalities choose to contract private providers to organise courses, instead of - or alongside - their internal, public providers (Fejes \& Holmqvist, 2019). In 2020, about 50 percent of MAE was organised by publicly funded, independent schools, mainly owned by private companies (SNAE, 2021b). There are also high levels of internal marketisation in MAE, in terms of quality assurance work and competition with other providers or organisers, including public, municipal-owned organisers (Andersson \& Muhrman, 2021a; Muhrman \& Andersson, 2021). However, regardless of which actor organises education, it is always the municipality that is responsible for its quality and accessibility for citizens.

Swedish MAE has its own curriculum (SNAE, 2017) which is enacted in the local education context within the frameworks (organisation and local policies) established by the municipalities. The focus of this article is on the enactment of the market orientation in vocational adult education, in terms of the organisation of flexible vocational education and training (VET) courses to meet students' needs, the labour-market orientation in the selection of what courses are offered to students, and how VET is employed as a tool for integration of immigrants, for example. These issues are governed by priorities set by both national and local policy decisions. As mentioned above, national policy decisions concerning MAE have increasingly shifted in recent years towards a labour market focus for MAE. However, there is a high degree of freedom within the policy, which means that local political decisions can have a major impact on what is enacted in MAE.

This study is about VET for adults within MAE. The purpose is to show how this form of vocational education is organised in Sweden and the reasons behind the policy enactment that can be seen in the local education context. The data consist of documents presenting relevant national policies for adult education, in particular vocational education, and semistructured interviews with adult education leaders.

Our article will answer the following research questions:

- How is vocational adult education organised in different ways in Swedish municipalities?

- How is national adult education policy enacted in local VET practices? 


\section{Context of the Study}

In addition to the marketisation, there has also been an extensive decentralisation of Swedish primary and secondary education, including adult education, where the local municipality have the responsibility for education, governed by the national policy (cf. Lundahl et al., 2013). There are 290 autonomous municipalities, who have their own political and administrative organisation, including the educational area. MAE is governed by the Education Act (2010) and the Adult Education Regulation (2011). Regardless of whether the training programmes are arranged by private or municipal providers, it is the municipality that is responsible for all municipal adult education, including general courses corresponding to the curricula for compulsory and upper secondary school, vocational courses at upper secondary level and courses in Swedish for immigrants (SFI). The courses included in MAE at upper secondary level have the same syllabuses as upper secondary school courses. However, the teaching is organised as separate courses or shorter training programmes (course packages) preparing students for a defined vocation, which are 0.5-1.5 years long compared to the three-year upper secondary school programmes (SNAE, 2017).

Adults are eligible to participate in municipal adult education at upper secondary level from the year they turn 20, if they are considered to meet the conditions to pass the courses. The municipalities are obliged to offer all applicants a place on basic courses (corresponding to compulsory school), SFI and courses for university eligibility. However, there is no requirement for the municipality to offer a place to everyone who applies for vocational courses within MAE. In the event that there are more applicants than places for a training programme, those who are considered to have the greatest need for the training shall be given priority. According to the policy documents (Adult Education Regulation, 2011), the supply of courses should be flexible in terms of study pace, distance course options and continuous admission. The municipality must offer all courses in general subjects via the municipality's own organisers, via external organisers or by purchasing study places from other municipalities, but the municipalities have the right to decide for themselves which vocational courses or training programmes to offer. As already mentioned, Swedish MAE is extensive. Among the 400,000 students in MAE in 2020, 107,000 studied at least one vocational course. Sixty percent of all students were women, and the majority had a foreign background (SNAE, 2021b).

To meet the need for an educated workforce, there are several government initiatives relating to VET in MAE. In particular, municipalities can receive subsidies for vocational adult education at upper secondary level within the so-called Yrkesvux ("vocational adult") initiative. This was introduced in 2009 with the aim of increasing the supply of vocational education within MAE through regional cooperation between municipalities, thereby counteracting a shortage of vocationally trained workers. There is a requirement, even for distance-based VET, that at least 15 percent of the time in training consist of a workplace internship. An initiative with similar conditions and requirements for cooperation between municipalities is 
available for apprenticeships at upper secondary level, called Lärlingsvux ("apprentice adult"), which also aims to increase the supply of vocational education. Here, a specific requirement is that at least 70 percent of the time should be spent in a workplace (and the rest at a VET school). It should also be noted that these apprentices are not employed by the workplace; they are adult students and do not receive a salary. A supervisor is assigned at the workplace, and the employer is compensated for taking on the apprentice. However, it is still the school and the teacher that are responsible for assessment and ensuring that the apprentice achieves the intended learning outcomes. The subsides for Yrkesvux and Lärlingsvux can also be used to finance VET in combination with SFI and SvA (Swedish as a second language). In addition to these initiatives, there is another initiative that is specifically aimed at training professional truckdrivers and bus drivers, also with requirements for cooperation between municipalities (Regulation of state subsidies for regional vocational adult education, 2016).

The marketisation of MAE means that there is a widespread system for procurement and tendering which the municipalities use to engage private education providers. It is the municipality that decides the conditions for procurement, and all tenderers must be treated equally based on the conditions set by the municipality. In recent years, an authorisation system has also been developed for MAE whereby the municipality sets the criteria for authorisation to organise adult education, and all providers who meet the criteria may arrange adult education as long as they meet the requirements. Unlike procurement, which only applies for a few years, there is no time limit for authorisation.

\section{Previous Research}

In the present article, we are studying the organisation of vocational adult education in the marketised MAE with a focus on the enactment of national policy. The marketisation of adult education is not a new phenomenon, as illustrated by Hake (2016) in a historical analysis of the development of a "post-initial training market" in the Netherlands, and there are a few studies concerning the marketisation of adult education that are conceptual or concerned with policy analysis (Fejes \& Olesen, 2016). However, empirical studies of the consequences of marketisation in adult education practices are sparse. In Sweden, where this study was conducted, marketisation is a widespread phenomenon. However, other studies show that the marketisation of education is also a global phenomenon. For example, Mikulec and Krašovec (2016) show how marketisation in Slovenian adult education policy is related to policy on a European level.

There are a few studies focusing on the marketisation of Swedish MAE in general (e.g. Bjursell, 2016; Bjursell et al., 2015; Fejes \& Holmqvist, 2019; Fejes et al., 2016; Holmqvist et al., 2021). Quality assurance systems have become important as a consequence of the marketisation of adult education with procurement by external providers, and how policy 
enactment at local, municipal level strongly influences the outcomes of the possibilities to control MAE (Fejes \& Holmqvist, 2019). This represents a tension between desirable market freedom and the possibility of administrative control and quality assurance that is often seen in marketised education systems (Bjursell, 2016; Rönnberg, 2012). In an earlier part of the current research project (Andersson \& Muhrman, 2021a), we provided an overview of how municipalities in Sweden combined internal and external MAE providers and chose different types of procurement for external courses. The study also showed the importance of quality control systems when hiring external providers. These systems are often extremely resourceintensive in administrative terms, which is one reason why several municipalities are considering extending the internal provision of courses.

When considering VET for adults from a broader perspective, more international studies are available. For example, there are several studies of adults' identity development in vocational education (e.g. Assarsson \& Sipos Zackrisson, 2005; Billett, 2007; Billett \& Sommerville, 2004; Brown et al., 2001). There are also a few studies that deal with various aspects concerning teaching adults (e.g. Bernal Castañeda, 2017; Choy \& Wärvik, 2018; van den Bogaart et al., 2016). However, there are not as many studies on the organisation of adult education on an overall level, or studies of how adult education policy is enacted in local VET practices.

The present state of vocational adult education in Sweden, concerning marketisation, is characterised by the extensive use of procurement and external, private providers. Swedish MAE has also gained an increasing labour market focus with more vocational education for adults, and marketisation has led to flexibility and good opportunities for adults to be admitted to VET. However, there are also organisational problems with short-term contracts that make it difficult to plan, and entail risks of over-establishment, etc., and difficulties controlling the quality of courses outsourced to many different organisers (Andersson \& Muhrman, 2019, 2021b). An attempt to achieve equivalent quality can be seen in Wärvik's (2013) study, where a quality assurance scheme was introduced by a VET provider in MAE to regulate teachers' work. The scheme involved standardising educational content and assessment, but also resulted in tensions concerning teachers' ability to keep to their own pedagogical ideas and to adapt teaching to the special needs of individual students.

The development of adult education in Denmark from the 1990s to the present day shows the same tendencies towards an increasingly strong labour market focus that can be seen in Swedish adult education (Rasmussen et al., 2019). In Denmark, decisions on adult education are being made to an ever greater extent within political networks that work closely with working life. The previous focus on diversity in adult education has become increasingly narrowed towards a focus on vocational education that meets the labour market's need for labour. Employers' associations have become important actors in decisions on various reforms and grants, and have also become partners in co-financing education. National investments have been made with large contributions aimed at expanding vocational education. 
The development of more labour market or "work orientation" has also been identified in the SFI curriculum, with more attention being paid to "occupational language" and making students employable. This could risk making the democratic and civic functions of adult education subordinate to the need for labour (Carlson \& Jacobsson, 2019). The Agency for Economic and Regional Growth (2018) in Sweden highlights this labour market orientation as municipalities increasingly offer SFI in combination with vocational education. Their evaluation shows that the integration of SFI and vocational education is positive for students' language learning and motivation, because they can practise language in an authentic context which makes learning more meaningful. It also improves labour market integration by contributing to the development of vocational identity and networks.

Participation patterns in adult education in Europe helps to understand the role of institutions and public policy frameworks in resolving coordination problems (Desjardins \& Rubenson, 2013). There are many different constraints for adults' participation in education, but even if it is the individual's decision to participate in adult education, political decisions governing adult education resources have a significant impact on the opportunities and limitations that exist in the provision of education and training places. Furthermore, not all participation in adult education is voluntary. There have been changes in the labour market which mean that, in some cases, adults are now more or less forced to participate in education due to demands from employers for formal professional competence (Desjardins \& Rubenson, 2013). Formal vocational training has also been identified as very important for establishment in Swedish working life. A study of young immigrants' opportunities for example showed that there are virtually no professions that do not require a minimum of upper secondary education and a degree (Knocke \& Hertzberg, 2000). The value of participation in education to be able to enter the labour market, create a future and become a part of Swedish society is confirmed in a more recent study where adult immigrant students describe their career choices and their futures (Dahlstedt \& Fejes, 2019a). The latter study raises questions about how adult education can de facto contribute to immigrants' desires for work and integration into society, and what kind of community immigrants are given the opportunity to be included in through adult education.

The group of adults who participate in vocational education is heterogenous concerning life paths and experiences, which makes it important to adapt the teaching to the individual (Masdonati et al., 2017). An investigation of vocational education that combines digital distance learning with on-site studies shows that digital teaching presents many barriers to students' learning, especially for what the researchers call "non-traditional" adult students and for students with a low socio-economic status (Safford \& Stinton, 2016). These challenges concerned everything from internet connection to taking notes, saving, storing, editing and reading online texts, and navigating and sorting the information that the students received digitally. Thus, a well thought-out pedagogy is needed for students to succeed with digital 
distance studies, and to ensure that there is not a high proportion of dropouts (Safford \& Stinton, 2016).

Adult education is thus expected to be flexible and individualised, but with a work orientation. More research is needed to understand the challenges in the enactment of adult education, and in this case particularly vocational education, to meet the wishes and needs of adult students, as well as the demands for labour in the labour market and for integration in society.

\section{$4 \quad$ Policy Enactment}

This study continues to analyse policy enactment (Ball et al., 2012; Braun et al., 2010) in Swedish adult education (Andersson \& Muhrman, 2021a; Holmqvist et al., 2021; Muhrman \& Andersson, 2021) with a focus on VET. From our perspective, the connection between education policy and practice is seen not as a rational process of implementation, but as a complex process of enactment that includes the interpretation and translation of policy into local practice (Ball et al., 2012). Maguire et al. (2015) put it as follows:

Policy is not 'done' at one point in time, it is always a process of 'becoming'. It is reviewed and revised as well as sometimes dispensed with or sometimes simply just forgotten. There will be multiple subjectivities and positions that will shape how policies are understood, and differences will occur in enactments over time and in different spatial contexts. Enactment then is messy, incomplete and a form of interpretation and intersubjectivity in action. (Maguire et al., 2015, p. 487)

In the local contexts of schools and authorities, multiple actors are involved in these complex processes, where policies are interpreted and translated, and enacted in local contexts in certain ways. Different policies might be contradictory, and the enactment in a local school context might therefore be messy and incomplete. Furthermore, less prescriptive, general policies include a certain degree of freedom for local translation and enactment. Nevertheless, there are certain policy discourses expressing what "good" teaching, teachers, students, etc. are, and these govern the enactment (Ball et al., 2012). In the case of Swedish adult education, the national policies do not prescribe exactly how MAE should be enacted. On the contrary, these policies have a certain degree of freedom, and local actors within the municipalities interpret and translate them into their own models of adult education. For example, the policy defines the adult student to be targeted as the one with the least prior education who still meets the conditions to pass the course, and this must be enacted in the selection of students.

Ball et al. (2012) also identified "master" discourses that define schooling - in their case learning, curriculum and behaviour. The latter discourse defines student behaviour as one of the central concerns in schools. In Swedish adult education, individualisation and flexibility 
have been identified as two central policy discourses. However, the master discourses that define Swedish adult education rather concern employability, skills supply, integration and not least marketisation (Muhrman \& Andersson, 2021). These discourses put the labour market and VET in focus when the policy is interpreted, translated and enacted in the practice of adult education.

\section{$5 \quad$ Methodology}

This article is part of a larger study in which we have used a policy enactment perspective to examine the organisation of municipal adult education, from political decisions to classroom teaching. The study as a whole consists of both qualitative and quantitative data in three parts. Firstly, a nationwide survey was distributed to adult education representatives in all Swedish municipalities (290). Secondly, qualitative interviews were conducted with MAE leaders in a sample of 20 municipalities, which were selected based on information from the first step and from official statistics on Swedish municipalities, to obtain a sample covering different types of municipality as well as different ways of organising MAE. These interviewees were heads of the local administration of adult education, who could report from the enactment of adult education in the municipality. Thirdly, a more extensive study was conducted in six of these municipalities, including in-depth, qualitative interviews with education leaders, with the intention of gaining a deeper understanding of how MAE is organised locally. Here, the education leaders also included principals of MAE schools.

This article focuses on vocational training within MAE, and the data consist of semistructured interviews from parts 2 and 3. Documents including relevant national policies on MAE, particularly concerning VET, have been used as a background. The interviews were recorded, transcribed and analysed thematically (e.g. Braun \& Clarke, 2006). In the article, quotations from the interviews are used to illustrate the findings. All interviews were conducted in Swedish, and the selected quotations have been translated into English.

We have treated all data confidentially, and have been careful to ensure that the empirical examples in the article should not be traceable to individual municipalities. We have anonymised the respondents, and have not reported which municipalities are included in the 20 selected for interviews and the six selected for extensive studies.

\section{Findings - VET Enacted in MAE}

MAE has a long tradition of offering a compensatory path to supplement earlier (unsuccessful) general studies and to provide eligibility for higher education. However, during the last decade, the labour market perspective of MAE has become evident. The skills supply function has been emphasised in policy, and a growing proportion of MAE consists of vocational 
courses in "packages" based on defined needs for skills supply in industries and trades, and a focus on employability and integration, with immigrants constituting a large target group.

Many MAE leaders in this study describe how investments and quality assurances in connection with MAE take place from a labour market perspective, to offer education that corresponds to working life's needs for labour and to make those who participate in education employable. One principal describes how the policy is interpreted and translated into an enactment of MAE where VET has a central position:

We have been given a clearer and clearer commission concerning vocational education. If you strain it or simplify it for the sake of clarity, municipal adult education was previously seen as a complement to upper secondary matriculation. Now we have a totally different situation. We pay more for vocational education, and it could be anything from salesmen to platers to truck drivers or assistant nurses. For example, when it comes to assistant nurses, I think that adult education accounts for the lion's share of the provision of assistant nurses.

As well as VET having been emphasised more in the national adult education policy, the education leaders describe a growing demand for VET courses from students and also from the municipal policy level. Most municipalities prioritise VET courses in MAE, even if they are not obliged to provide such courses. The translation of national policy into local policy conforms to the national level. Therefore, there are extensive opportunities to be admitted to VET as an adult, as well as good opportunities for employment afterwards. However, despite the increasing demand, a number of education leaders also describe problems in the enactment concerning the recruitment of students to certain VET courses. This challenge will be discussed later in this article.

\subsection{Ways of Organising Flexible VET}

Flexibility and individualisation are enacted not least in terms of how VET in MAE is organised. These policy discourses are interpreted and translated into different ways of organising courses, based on the expressed intention that they should suit students with different preconditions and needs. The marketisation discourse interacts with flexibility when different providers are procured to organise courses in different ways.

Vocational training within MAE is conducted either by internal provision or by the municipalities engaging external providers. The municipalities offer VET as school-based training, apprenticeships and/or distance education. It is also increasingly common to offer combinations of VET and SFI courses. It should also be noted that a municipality can buy study places from other municipalities. In these cases, it can be difficult for the buying municipality to decide how VET is arranged. 
Many MAE representatives consider apprenticeship training to be a good alternative for VET that provides work experience and often leads to employment. Most municipalities therefore offer VET as apprenticeships, in addition to school-based courses. Many of the interviewed education leaders describe how the municipality gives students a choice between these two alternatives, but some municipalities particularly use the apprenticeship as an alternative in vocations where they lack training facilities and teachers.

However, the national subsidies for apprenticeships are not used to the same extent as those for school-based VET. The education leaders describe problems recruiting apprentices for many different reasons. The tradition of apprentices has largely vanished in Sweden, and even if initiatives have been taken to reintroduce apprenticeships (Olofsson \& Persson Thunqvist, 2018) it is not well-known among potential apprentices how an apprenticeship works in the MAE system, leading to a sense of reluctance. The education leaders also describe how students want to be in a social context with other students, and that "those who start as apprentices soon want to return to school". In addition to the low interest among potential apprentices, the education leaders also describe other problems concerning the enactment of policy initiatives for apprenticeship training. A certain amount of organisational and administrative work is required for individualised apprenticeships. Supervisors and teachers need good skills, and the apprentices must be interested and skilful. The remuneration paid to the employer is not considered to cover the extra work needed from the employer to take care of an apprentice, which is one reason why small companies with a high workload do not want apprentices. One principal describes the situation:

We do have apprenticeship training, but it is somewhat tricky as the schools must do more administrative work and establish apprentice contracts between the school and the employer, and there is not always good matchmaking between the student and the employer, and then there is also more administration with different forms of compensation paid to the school for teaching and to supervisors, and the training of supervisors, so this training is more complicated. And sometimes I think that the rules from the National Agency of Education are a little too rigid in terms of which courses and volumes and everything, but generally I believe that apprenticeship training is very good.

Distance education is another enactment of flexibility. On the most common VET courses, which are mainly within healthcare, 20-30 percent of students typically took the course in the form of distance education (before the pandemic, when distance courses became normal). Here, the theoretical aspects of the vocation are studied remotely, but workplace-based learning with a focus on the practical aspects is, as mentioned, also part of the package. In terms of flexibility and accessibility, distance education creates study opportunities for people who have difficulties participating in on-site training due to factors such as work, long travelling times or having young children. Distance education also increases the skills supply, since students can be offered a wider range of training programmes. 
However, education leaders are concerned that distance education might hinder the development of social skills, which are demanded by employers. This is particularly seen as a potential problem in service vocations such as caring, and some municipalities are therefore reducing the extent of distance education and promoting school-based courses particularly in VET.

We have become more and more restrictive when it comes to distance education. Only students with special reasons, such as work or parental leave, are offered distance education. I believe that the students get better training if it is not delivered remotely, and students need to meet other students and teachers to develop social competence, which is strongly demanded by employers. Employers want socially competent people with drive and commitment.

\subsection{VET for Which Vocations?}

Vocational adult education is enacted not only in different ways of organising courses, but also in which vocations are included in the course offering. It is not compulsory for municipalities to offer vocational courses for adults, which means that they can decide locally which vocations should be taught via MAE.

Nevertheless, the government initiatives for VET affect the range of training programmes within MAE. Virtually all municipalities participating in our study receive the subsidies available for VET in MAE. This means that they can offer more study places in VET than they would otherwise have been able to. However, in addition to the targeted subsidy for professional drivers, municipalities are free to choose which training programmes they want to invest these subsidies in.

The supply of VET is therefore enacted at the intersection of interpretations and translations of the individualisation and skills supply discourses. The individual demands are considered important, but so too are labour market needs and employability. The translation and enactment of these potentially contradictory discourses can differ between municipalities. For example, education leaders in larger municipalities describe a lack of labour in most vocational areas, which means that individual demand could be allowed to have a stronger influence - all VET alternatives would still provide employability and skills supply. Smaller municipalities, on the other hand, might have specific industries and vocations with a high demand for labour which governs the local priorities.

There is extensive collaboration and contact with the employment office, industries and trades, labour market councils, etc., to predict the need for labour. These predictions form the basis for prioritising the supply of VET courses, where for example courses in industrial technology, truck and bus driving, and training for cooks are typically included. As mentioned, there are also programmes where VET is combined with SFI, and these and other 
VET programmes are governed by labour market demands. As a result, employability and finding the "right" students are important. One principal illustrates the challenges:

The labour market needs are important here, to be able to devise a combined programme that results in employment rather than being a sort of temporary holding service for an industry without any demands. Good labour market connections are crucial, to avoid saturating the market as it were, or to start sniffing out other areas where you see that, here it is actually possible for an immigrant student to come through and to get a job later on. But the challenge involves both maybe directing the students more strictly towards different vocations, but also getting the right students who can pass the programme and get a job afterwards.

As mentioned, some VET programmes experience low demand from students, even if the labour market demand and employability are high. The principals typically have no explanation for this low student demand, but think it is a matter of lacking knowledge about these vocations:

In this region they are crying out for most of them. But the students don't apply for all programmes, for example they don't know what a CNC operator is. And few want to be cooks, and so on. The industries must market themselves to get applicants and new labour. For example, truck mechanics, Scania and MAN started to promise probationary employment after training, and then there were lots of applicants. So, we try to reach partnership agreements with the industries. Otherwise, many of them apply to health and social care, as this is what many of them know about, particularly newly arrived [immigrants].

Another problem that restricts the extent of school-based VET and apprenticeship training in certain vocations is the lack of placements. Some principals describe how the school does not always have a good connection to working life, and therefore has difficulties finding supervisors at workplaces that want apprentices. There is also "competition" with other VET providers that also need placements, particularly for students from upper secondary school. Some employers feel that apprentices have too little knowledge, and that supervising them would be too much work, even if there is a need for labour.

\subsubsection{Short Contracts and a Shortage of Teachers Affect the Supply of VET}

There are also market-related challenges in the Swedish system of VET for adults that influence the range of vocational training: The procurement of external providers and the high demand for teachers. The marketisation of MAE with the procurement of external providers could be a particular challenge in VET. Public procurement means short-term contracts for VET. The providers are hesitant about submitting tenders to offer courses that require extensive investments when they only will get a four-year contract, and this may affect the supply of training for certain professions. 
The disadvantage is the very fact that it is only for four years. Think about it, how could you dare to invest in buying materials, premises, with long contracts, yes, everything, when you only are safe for four years? [...] No, an extreme example could be that we currently have training for $\mathrm{CNC}$ operators, and every computerised machine might cost millions. And you might need 10, 15 such machines to cover the whole training programme. It isn't possible. It's not reasonable to imagine that it would work.

This is one reason why the authorisation system has been introduced in some municipalities. The intention is to establish long-term relationships with external providers who do not risk losing the contract after just a few years.

Another challenge which may affect the range of vocational training offered within MAE is the lack of trained VET teachers in Sweden. Some principals were even suspicious if they found a qualified VET teacher who was not already employed.

There are almost no qualified vocational teachers, and those who are available, you start wondering why they are not employed, if there are any qualified teachers who are not employed. So it's hard to find them. Very, very hard.

Swedish VET teachers typically have a background in a basic vocation which they now teach, and a double competence as both teachers and skilled workers in this vocation. Thus, the problem of the supply of teachers increases with the short-term labour market focus of MAE, where VET is expanding in areas with a current labour-market demand - a demand where the teachers also are attractive as workers in their basic vocations.

\subsubsection{Adult Education as a Buffer}

A specific demand from municipal services for labour within elderly care and childcare is described by education leaders in many municipalities. By far the most common VET programmes in Swedish MAE are healthcare and elderly care, and childcare and recreation, with 39 and 21 percent respectively of those students who studied VET courses corresponding to at least 0.5 years of full-time studies in 2020 (SNAE, 2021b). What we see here is that MAE becomes a supplementary institution in relation to upper secondary school, where these programmes only had 10 percent each of all VET students in 2020/21 (SNAE, 2021a). A low demand for VET compared to labour-market needs among young students in certain areas results in decisions that prioritise these vocational areas in VET for adults - MAE becomes a "buffer" to meet the needs of these services.

These courses also have many applicants, not least among immigrants, which the education leaders explain as a result of the high demand in the labour market. The demand among applicants has been so high that a selection process could be necessary, particularly for the childcare and recreation programme. Otherwise, all applicants for adult VET are often admitted. 
Adult VET could also become a buffer in another way. If there are few applications from young people for VET programmes in upper secondary education, there will be empty places at the VET school which could be filled with adult students. It becomes possible to expand MAE without procuring external providers. One principal explains what could happen:

I think that adult education is used as a filler. To be honest, this is how it is. It is not obvious that that there must be X study places in... just as an example... HVAC [heating, ventilation, and air conditioning]. Rather, it is filled up [with adult students] when the upper secondary school students do not choose that programme. It is quite a clear prioritisation really, which one might have opinions about. But that's the way it is.

\subsection{VET for Integration}

The integration discourse is also strong in MAE, and not least in VET. A large number of students have foreign backgrounds, and integration and employability interact with skills supply in the enactment. As mentioned, VET in the areas of elderly care and childcare is popular among immigrants, and has thus become a tool for integration. Many participants on the programmes that supply skills to municipal services are immigrants, who know that training in these areas often enables them to become established in the labour market. Apprenticeships are also considered to improve employability, and are therefore promoted as a good way for immigrants to become established in the labour market. All this fits well with the need to promote the integration of immigrants in society, where employment is seen as crucial to be able to make a living.

However, this interaction between integration, employability and skills supply is not entirely consistent with the discourses of individualisation and flexibility. On the one hand, these VET programmes are popular among immigrants. However, on the other hand, the theoretical courses that prepare students for higher education are also popular. The education leaders say that many immigrants want to study theoretical courses to become eligible for higher education. They also want to avoid large study loans, and see VET as a side track when the ambition is to enter higher education, which they have learnt is important and open to everyone in Sweden.

Vocational education has exactly the same duration that higher education preparatory education might have, so you might think that it is unnecessary to take vocational training.

That you burn your economic resources, as it were.

Another challenge for VET concerning the potential for integration is the immigrants' backgrounds when it comes to language and culture. Some vocations and VET programmes have increased the Swedish language requirements, with a certain level being required to be able to do what is seen as a good job. Therefore, for example, the number of applicants to become 
assistant nurses has decreased in some municipalities in recent years, as the Swedish language requirements have become tougher and many of the potential applicants have little proficiency in Swedish. This leads to - and illustrates - the challenges of merging individualisation and integration.

One aspect of this language challenge concerns work placements and the perceived respective responsibilities of schools and workplaces. Some employers believe that they have a responsibility, and that it is important for students to get out and learn Swedish in real-life workplaces, while others believe that students should not be in a workplace until they have sufficient language skills.

The education leaders also identify potentially problematic cultural factors such as clothing and beliefs concerning certain foodstuff. The students should be prepared for a vocation where a large part of Swedish elderly care takes the form of home care, and where care workers must be able to perform all tasks themselves.

And, of course, with cultures come language problems, but also sometimes their traditions, which might clash with the content of our courses. For example, not having a full understanding for how we work in healthcare and elderly care, or how we work with children in the educational aspects of Swedish society, and this might cause problems in certain situations. For example, if you are going to a placement in elderly care, you might work at a homecare unit. Many workers at homecare units or companies cycle at work, and there are many of these women and men who cannot ride a bicycle, and that is a barrier to taking this placement. Then there are some who don't understand that they must agree to give a shower, a woman must be able to give a strange man a shower, and vice versa. You must be able to serve food such as pork, and so on, because this is what this care recipient is used to eating, and then they [the students] have views that according to their tradition and religion they cannot touch [pork] and so on. And then there are rules concerning clothing. Are you allowed to wear a shawl, are you allowed to wear full-length sarongs and so on? There are many such things that we must start to understand and talk about to understand each other and our cultures.

\subsection{1 "Combined Programmes"}

To reduce the time that students with immigrant backgrounds spend in adult education and to improve their employability, education leaders describe that they have worked for several years to increase the opportunities to combine SFI with VET. This has been successful, and - as mentioned above - there are now also government subsidies for conducting VET in combination with SFI and SvA. This means that combined programmes are developed in several municipalities. Local policy initiatives are taken to find solutions for combining courses. For example, one municipality describes a proposal to make it compulsory to combine SFI with other courses. The ideal is to have tracks where immigrants with an academic background should be offered SFI combined with theoretical courses providing eligibility for 
higher education, while immigrants with shorter educational backgrounds should combine SFI with VET, and it should also be possible to combine SFI with a work placement.

Those municipalities that offer these combined programmes describe positive outcomes concerning the development of language and employability.

SFI has made up about 50 percent of adult education. We have been working a lot with how to combine SFI and other courses. For example, we have vocational SFI where you can take vocational training in parallel with SFI. The aim is that the students should be able to start vocational education as early as possible, and it's easier to develop language in a vocational context. Language and vocational education strengthen each other.

The combined programmes are often organised in cooperation with local businesses. The selection of VET courses is based on local needs rather than nationally proposed "packages", described as follows by one principal:

Yes, all combined programmes, before we start a new programme, the employers should be there from the beginning. We have an idea of an employment track. That is probably where we have been working most with the employers now. Placements. And quality assurance that this programme actually results in employability. Because we haven't exactly used the national vocational course packages in the combined programmes. [...] So we've produced local packages, and then companies have been involved in the preparation of each new combined programme.

Furthermore, some of the education leaders describe the development of a model in schoolbased combined programmes where language (Swedish) and VET teachers work together in the classroom. The education leaders see the advantage of teachers planning their teaching together, which makes for a cohesive whole with a natural connection between language teaching and vocational teaching.

In summary, Swedish VET for adults is extensive and flexible. However, the supply is also strongly influenced by market forces, the need for labour in certain vocations, and the intention to use VET as a tool for integration.

\section{Discussion}

Vocational adult education in Sweden is organised locally in different ways, where the adult education policy is interpreted, translated and enacted in certain ways by the municipalities, depending on their local conditions and need for labour.

In the wake of marketisation, several different providers of vocational training can be seen, as well as different ways of conducting vocational training. Vocational training is offered as on-site, distance and apprenticeship training through municipal providers, external private training providers and various collaboration agreements between the municipalities. 
The advantages of this are that there are good opportunities for everyone who wishes to take part in vocational training, in terms of both access to training places and, with distance alternatives, accessibility for those who want to combine education with work, for example. The organisation of MAE, with outsourcing to private providers and a combination of schoolbased and distance courses, is a way of enacting policy for MAE in general (cf. Fejes \& Holmqvist, 2019; Holmqvist et al., 2021). The heterogenous group of adults in vocational education (cf. Masdonati et al., 2017) makes flexibility central, with an intention to meet the needs of adults with different life situations - adults who are to become employable and integrated into society. However, this flexible approach brings organisational problems, including shortterm procurement contracts with external providers that make it difficult to plan and the risk of over-establishment when the same courses are offered by several authorised providers (cf. Andersson \& Muhrman, 2019, 2021a). Problems are also identified concerning the outcomes of flexible distance courses, such as lack of development of social skills, which are needed in the labour market, and this is a reason for providing more school-based and fewer distance-based courses. Furthermore, studies show that there may also be other challenges when providing distance VET education for adults, which means that they risk achieving poorer results or dropping out of the training (Safford \& Stinton, 2016; cf. Muhrman \& Andersson, 2021).

Swedish adult education has a strong labour-market perspective (cf. Rasmussen et al., 2019), in which VET plays a central role, and the employability and (labour-market) integration of immigrants are central concerns. Combined programmes integrate VET and Swedish language courses (cf. Carlson \& Jacobsson, 2019). There are targeted policy initiatives to strengthen the position and expand the supply of VET in adult education, and to encourage regional cooperation between municipalities. Despite this, the range of different vocational courses and programmes within MAE is not as large as the number of training places would allow. There is a strong focus on providing VET within certain vocational areas within municipal services such as elderly care and childcare. This raises questions about whether publicly funded VET for adults is mainly intended to prepare for these publicly funded labourmarket sectors, and what the consequences of not prioritising broader employability among unemployed adults are. There should be other sectors that could also benefit from newly trained workers. However, this prioritisation indicates that vocational adult education has a supplementary role in relationship to VET in upper secondary education, which has a broader offering of different programmes. This supplementary role is obvious also when adult education becomes a "filler" in upper secondary education classes. That is, VET for adults is mainly offered in sectors where VET programmes do not attract enough young people. The labour-market integration of immigrants thereby seems to be narrowed to a few vocational sectors (cf. Dahlstedt \& Fejes, 2019a; Desjardins \& Rubenson, 2013). Offering training only in certain sectors might result in a subordinate inclusion in the labour market, considering 
the importance of formal vocational education for such inclusion (cf. Knocke \& Hertzberg, 2000). To understand these prioritisations, the influence of interplay between market forces and administrative control (Bjursell, 2016; Rönnberg, 2012) in Swedish MAE should be analysed in more detail.

Finally, workplace-based learning and placements are required in VET, be it a schoolbased, distance-based or apprenticeship programme. Here, we see a problem with the shared responsibility between schools and employers in Swedish VET. Even if the school has extensive responsibility for VET in this context, employers must still take their responsibility and provide placements. However, there could be problems gaining access to workplaces and placements. We have described employers' involvement in the development of the combined programmes, but it seems that other employers see neither the potential of placements for recruiting labour nor the value of the workplace as a learning context for developing vocational skills and, particularly in the case of immigrant students, vocational language. Rather, expectations seem to be placed on schools to "deliver" fully trained employees. Here, the Swedish VET and labour market would, even with a mainly school-based VET system, benefit from closer cooperation and a shared responsibility. The development of more combined programmes might contribute to this.

\section{Acknowledgement}

This work was supported by the Swedish Research Council under Grant number 2017-03603.

\section{References}

Adult Education Regulation. (2011). Utbildningsdepartementet (SFS 2011:1108). https://www.riksdagen.se/sv/dokument-lagar/dokument/svensk-forfattningssamling/forordning-20111108-omvuxenutbildning_sfs-2011-1108

Agency for Economic and Regional Growth. (2018). Utbildning i yrkessvenska och svenska för företagare: Kartläggning av metoder [Courses in vocational Swedish and Swedish for entrepreneurs: A mapping of methods]. Tillväxtverket. https://tillvaxtverket.se/vara-tjanster/publikationer/publikationer-2018/2018-05-07-utbildning-i-yrkessvenska-och-svenska-for-foretagare.html

Andersson, P., \& Muhrman, K. (2019). Marketization of vocational adult education in Sweden. In F. Marhuenda \& M. J. Chisvert-Tarazona (Eds.), Pedagogical concerns and market demands in VET. Proceedings of the 3rd Crossing Boundaries in VET conference, Vocational Education and Training Network (VETNET) (pp.153-157). https://doi.org/10.5281/zenodo.2640958

Andersson, P., \& Muhrman, K. (2021a). Marketisation of adult education in Sweden. Journal of Adult and Continuing Education. https://doi.org/10.1177/14779714211055491

Andersson, P., \& Muhrman, K. (2021b). The local organisation of vocational adult education in Sweden. In C. Nägele, B. E. Stalder \& M. Weich (Eds.), Pathways in vocational education and training 
and lifelong learning. Proceedings of the 4th Crossing Boundaries Conference in vocational education and training (pp. 51-55). https://doi.org/10.5281/zenodo.4537180

Assarsson, L., \& Sipos Zackrisson, K. (2005). Iscensättande av identiteter i vuxenstudier [Staging identities in adult education] [Doctoral dissertation, Linköping University]. http://liu.diva-portal.org/ smash/get/diva2:20461/FULLTEXT01.pdf

Ball, S. J., Maguire, M., \& Braun, A. (2012). How schools do policy: Policy enactments in secondary schools. Routledge.

Bernal Castañeda, S. (2017). Lifelong learning and limiting factors in second language acquisition for adult students in post-obligatory education. Cogent Psychology, 4(1), 1404699. https://doi.org/10. 1080/23311908.2017.1404699

Billett, S. (2007). Exercising self through working life: Learning, work and identity. In A. Brown, S. Kirpal \& F. Rauner (Eds.), Identities at work (pp. 183-210). Springer.

Billett, S., \& Somerville, M. (2004). Transformations at work: Identity and learning. Studies in Continuing Education, 26(2), 309-326. https://doi.org/10.1080/158037042000225272

Bjursell, C. (2016). When theories become practice: A metaphorical analysis of adult-education school-leaders' talk. European Journal for Research on the Education and Learning of Adults, 7(2), 191-205. https://doi.org/10.3384/rela.2000-7426.rela9084

Bjursell, C., Chaib, C., Falkner, C., \& Ludvigsson, A. (2015). Kvalitetsarbete i vuxenutbildning [Quality work in adult education]. Nomen, Encell rapport 1:2015. https://www.diva-portal.org/smash/get/ diva2:810681/FULLTEXT02.pdf

Braun, A., Maguire, M., \& Ball, S. J. (2010). Policy enactments in the UK secondary school: Examining policy, practice and school positioning. Journal of Education Policy, 25(4), 547-560. https://doi. org/10.1080/02680931003698544

Braun, V., \& Clarke, V. (2006). Using thematic analysis in psychology. Qualitative Research in Psychology, 3(2), 77-101. https://doi.org/10.1191/1478088706qp063oa

Brown, A., Koniordos, S., Laske, G., Loogma, K., Marhuenda, F., Navas, A., Stryjecka-llina, O., \& Vilu, R. (2001). Changing vocational identities in Europe: How vocational identities are decomposed and reconstructed in the Czech Republic, Estonia, France, Germany, Greece, Spain and the United Kingdom. Paper presented at the Work, Employment and Society conference on winning and losing in the new economy (WES 2001) at the University of Nottingham, 11th - 13th September 2001.

Carlson, M., \& Jacobsson, B. (2019). Neoliberalising adult education. In M. Dahlstedt \& A. Fejes (Eds.), Neoliberalism and market forces in education: Lessons from Sweden (pp. 123-137). Routledge.

Choy, S., \& Wärvik, G.-B. (2018). Integration of learning for refugee and migrant students: VET teachers' practices through practice theory lens. Journal of Vocational Education \& Training, 7(1), 87-107. https://doi.org/10.1080/13636820.2018.1518921

Dahlstedt, M., \& Fejes, A. (2019a). Futures in line? Occupational choice among migrant adult students in Sweden. International Journal of Lifelong Education, 38(1), 76-87. https://doi.org/10.1080/0260 1370.2018.1497719

Dahlstedt, M., \& Fejes, A. (Eds.) (2019b). Neoliberalism and market forces in education: Lessons from Sweden. Routledge.

Desjardins, R., \& Rubenson, K. (2013). Participation patterns in adult education: The role of institutions and public policy frameworks in resolving coordination problems. European Journal of Education, 48(2), 262-280. https://doi.org/10.1111/ejed.12029 
Education Act. (2010). Utbildningsdepartementet (SFS 2010:800). https://www.riksdagen.se/sv/dokument-lagar/dokument/svensk-forfattningssamling/skollag-2010800_sfs-2010-800

Fejes, A., \& Holmqvist, D. (2019). Procurement as a market in adult education. In M. Dahlstedt, \& A. Fejes (Eds.), Neoliberalism and market forces in education: Lessons from Sweden (pp. 156-169). Routledge.

Fejes, A., \& Olesen, H. S. (2016). Editorial: Marketization and commodification of adult education. European Journal for Research on the Education and Learning of Adults, 7(2), 146-150. https://doi. org/10.3384/rela.2000-7426.relae12

Fejes, A., Runesdotter, C., \& Wärvik, G.-B. (2016). Marketisation of adult education: Principals as business leaders, standardised teachers and responsibilised students. International Journal of Lifelong Education, 35(6), 664-681. https://doi.org/10.1080/02601370.2016.1204366

Hake, B. (2016). Regulatory governance of 'training markets', 'market failure', and 'quasi' markets: Historical dimensions of the post-initial training market in The Netherlands. European Journal for Research on the Education and Learning of Adults, 7(2), 171-189. https://doi.org/10.3384/ rela.2000-7426.rela9080

Holmqvist, D., Fejes, A., \& Nylander, E. (2021). Auctioning out education: On exogenous privatisation through public procurement. European Educational Research Journal, 20(1), 102-117. https://doi. org/10.1177/1474904120953281

Knocke, W., \& Hertzberg, F. (2000). Mångfaldens barn söker sin plats: En studie om arbetsmarknadschanser för ungdomar med invandrarbakgrund [The children of diversity are looking for their place: A study on the labour market opportunities for young people with an immigrant background]. Arbetslivsinstitutet.

Lundahl, L., Erixon Arreman, I., Holm, A.-S., \& Lundström, U. (2013). Educational marketization the Swedish way. Education Inquiry, 4(3), 497-517. https://doi.org/10.3402/edui.v4i3.22620

Maguire, M., Braun, A., \& Ball, S. (2015). 'Where you stand depends on where you sit': The social construction of policy enactments in the (English) secondary school. Discourse: Studies in the Cultural Politics of Education, 36(4), 485-499. https://doi.org/10.1080/01596306.2014.977022

Masdonati, J., Fournier, G., \& Lahrizi, I. Z. (2017). The reasons behind a career change through vocational education and training. International Journal for Research in Vocational Education and Training, 4(3), 249-269. https://doi.org/10.13152/IJRVET.4.3.4

Mikulec, B., \& Krašovec, S. J. (2016). Marketising Slovene adult education policies and practices using mechanisms of the Europeanisation of education. European Journal for Research on the Education and Learning of Adults, 7(2), 151-170. https://doi.org/10.3384/rela.2000-7426.rela9081

Muhrman, K., \& Andersson, P. (2021). Adult education in Sweden in the wake of marketisation. Studies in the Education of Adults. https://doi.org/10.1080/02660830.2021.1984060

Organisation for Economic Co-operation and Development. (OECD) (June 2020). Learning for life. https://www.oecd.org/education/learningforlife.htm

Olofsson, J., \& Persson Thunqvist, D. (2018). The modern evolution of VET in Sweden (1945-2015). In S. Michelsen \& M.-L. Stenström (Eds.), Vocational education in the Nordic countries: The historical evolution (pp. 124-145). Routledge.

Rasmussen, P., Larson, A., \& Cort, P. (2019). The vocational turn of adult education in Denmark: An analysis of adult education policy from the late 1990s. International Journal of Lifelong Education, 38(3), 254-267. https://doi.org/10.1080/02601370.2019.1586778 
Regulation of state subsidies for regional vocational adult education. (2016). Utbildningsdepartementet (SFS 2016:937). https://www.riksdagen.se/sv/dokument-lagar/dokument/svensk-forfattningssamling/forordning-2016937-om-statsbidrag-for-regional_sfs-2016-937

Rönnberg, L. (2012). Reinstating national school inspections in Sweden: The return of the state. Nordic Studies in Education, 32(2), 69-83.

Safford, K., \& Stinton, J. (2016). Barriers to blended digital distance vocational learning for non-traditional students. British Journal of Educational Technology, 47(1), 135-150. https://bera-journals. onlinelibrary.wiley.com/doi/epdf/10.1111/bjet.12222

Swedish National Agency of Education. (SNAE) (2017). Läroplan för vuxenutbildningen. Reviderad 2017 [National curriculum for adult education. Revised 2017]. Skolverket. https://www.skolverket. se/getFile?file $=3814$

Swedish National Agency of Education. (SNAE) (2021a). Elever i gymnasieskolan läsåret 2020/21 [Students in upper secondary school year 2020/21]. Skolverket. https://www.skolverket.se/ getFile?file $=7826$

Swedish National Agency of Education. (SNAE) (2021b). Elever och studieresultat $i$ kommunal vuxenutbildning 2020 [Students and study results in MAE 2020]. Skolverket. https://www.skolverket.se/ getFile?file $=8251$

van den Bogaart, A. C. M., Bilderbeek, R. J. C., Schaap, H., Hummel, H., \& Kirschner, P. A. (2016). A computer-supported method to reveal and assess personal professional theories in vocational education. Technology, Pedagogy \& Education, 25(5), 613-629. https://doi.org/10.1080/147593 9X.2015.1129986

Wärvik, G.-B. (2013). The reconfiguration of adult education VET teachers: Tensions amongst organisational imperatives, vocational ideals and the needs of the students. International Journal of Training Research, 11(2), 122-134. https://doi.org/10.5172/ijtr.2013.11.2.122

\section{Biographical Notes}

Per Andersson is a professor of education at the Department of Behavioural Sciences and Learning at Linköping University, Sweden. His research interests focus on recognition of prior learning, professional development among teachers in vocational and adult education, and marketisation of adult education.

Karolina Muhrman is an associate professor of education at the Department of Behavioural Sciences and Learning at Linköping University, Sweden. Her research interests focus on the teaching of mathematics in vocational education, and marketisation of adult education. 